\title{
Study of Blood lead level and its impact on intelligence of children below 12 years of age
}

\author{
Verma $\mathbf{J}^{1}$, Gaur $\mathrm{A}^{2}$, Ahirwal $\mathbf{K}^{3}$, Flora $\mathbf{S J S}^{4}$ \\ ${ }^{1}$ Dr. Jyotsna Verma, Department of Pediatrics, L.N. Medical College, Bhopal, ${ }^{2}$ Dr Ajay Gaur, Department of Pediatrics, \\ Gajra Raja Medical College, Gwalior, ${ }^{3}$ Dr. Kamlesh Ahirwal, District. Hospital Panna, M.P, ${ }^{4}$ Dr SJS Flora, joint Director, \\ Division of Pharmacology and Toxicology, DRDE, Gwalior, MP, India
}

Address for Correspondence: Dr. Jyotsna Verma, Email: drjyotsnaverma@gmail.com

\begin{abstract}
Introduction: The Present study is an attempt to assess the level of lead in blood in general population and it's Impact on intelligence. Methods: A random sample of 70 children between the ages of 1-12 year's residing in and around Gwalior region, attending Pediatrics OPD of GRMC Gwalior, constituted the material for study. A detail history and examination was done to asses various factor affecting lead status of child. Blood lead level was assessed at DRDE Gwalior and Intelligence was also assessed simultaneously. Results: On data analysis more than $50 \%$ off study group was found to have blood lead level above safe level (10 $\mathrm{mcg} / \mathrm{dl}$ ). On analysis of effect of raised lead level on intelligence, it was found that raised blood lead level was associated with decrease in IQ. At various lead levels IQ status were as following, at lead level of $0-5 \mathrm{mcg} / \mathrm{dl}$; IQ 96.64\%, 5 - $10 \mathrm{mcg} / \mathrm{dl}$; IQ $94.33 \%, 10-15 \mathrm{mcg} / \mathrm{dl}$; IQ $89.05 \%, 15-20 \mathrm{mcg} / \mathrm{dl}$; IQ $79.75 \%$ and at lead level more than $20 \mathrm{mcg} / \mathrm{dl}$; IQ 73.8\%. This decrease in intelligence level with increase in blood lead level was statically significant. Conclusion: A healthy appearing child may have silent lead poisoning affecting his intelligence without clinically apparent symptoms and signs until much later in life. High degree of suspicion, in a child with history of pica and poor nutrition status should be there for early diagnosis.
\end{abstract}

Keyword: lead level, Pica, impact on intelligence.

\section{Introduction}

Nation's most valuable asset are their children, in order realize their full potential children need to grow up in an environment that is safe and supportive. Among the various toxic elements in atmosphere lead has been found to act as slow poison for intelligences at sub clinical level. Lead being the most widely scattered toxic material in the world, the blood lead level found in apparently healthy population is considered as normal blood lead level ( $<10 \mathrm{mcg} / \mathrm{dl})$, although no level of lead in blood is safe or ingestion or inhalation.

Various sources of lead in and around our surrounding are automobile exhaust, lead paints on walls, toys, tradition of wrapping food in news paper, working of child or parents at battery shop or related jobs. The George Foundation under the "Project Lead Free" assessed blood lead level of 22,000 children from seven major cities of India and concluded that $51 \%$ of children up to $12 \mathrm{yrs}$, had blood lead level more than $10 \mathrm{mcg} / \mathrm{dl}$ [1]. Children are more prone to lead poisoning because of increase hand to mouth activity, Habit of Pica, increase Gastric absorption due to presence of multiple vitamin \& micro nutrient deficiencies. The measurement of lead level in general population is the most useful indicator of the toxic effect of slow silent poison. The effect of lead on cognitive \& behavioural development at low level of lead in blood is critical on infants \& children and is the focus for current prevention strategies.

\section{Material and Methods}

\section{Setting and Samples:}

A random sample of 70 children of age less than 12 year's constituted the material for this study.

A random sample was taken from children attending Pediatrics Out Patient Department of G. R. Medical College, Gwalior, India. A well informed consent of parent's and permission from Institutional research board has been taken for study.

Available online at: www.ijmrr.in 12 | P a g e 


\section{Exclusion criteria}

1.Children more than 12 years of age. 2. Children with clinical sub mental-sub normality.

3. CNS disease.

4. Those who were sick to perform intelligence test.

\section{Question form}

For every child who was included in this study a detailed clinical history to assess demographic data such as age, sex, residence and various factors affecting lead status of the child was assessed.

Factors that affect lead status of a child includes residence in $\&$ around lead exposure area (batteries shop, heavy traffic area), occupation of father related to lead and in case of working child exposure at working place of lead, history of pica.

\section{Clinical examination}

A detailed clinical examination to assess nutritional status and multiple vitamin's and micro nutrients deficiency which increases lead absorption from gastrointestinal tract has been assessed.

\section{Laboratory investigation}

Blood lead level along with other parameter like complete Blood count for anemia was estimated by auto analyzer at DRDE (Defence Research and Development Establishment) research lab at Gwalior.

\section{Intelligence test}

To assess the impact of various blood lead level on intelligence, IQ status of the child was assessed by using two tests.

1. Development screening test (design by J. Bharat Raj, Professor \& Head Department of clinical psychology, All India institute of speech and hearing Mysore). 2. Sanguine form board test (Performance test)

Development screening test - It consisted of 88 items which represent behavioural characteristics of respective age level. Appraisal of the child was done starting from basal age were all characteristics of a particular age was passed and gradually moving through upper age level. Testing was done in semi structured interview with parents. Having obtained the mental age IQ calculator was used.

Sanguine form board test - This test can be performed to assess the IQ of children from 3 years to 12 years of age. The board had 10 wooden block of different shape. While performing this test this block were taken out by examiner and stacked in front of subject, Who had to put them back in appropriate space as quickly as he could, the task was repeated 3 times, the score that was of shortest time was taken .This performance test shows the subject ability to respond to pressure for speed and his performance when faced with difficulty.

Statistical Method: Correlation coefficient has been measured between serum lead level and IQ level. $\mathrm{P}<0.05$ was taken as significant. The data were analyzed by using SPSS software.

\section{Results}

Table 1: shows age wise distribution of study group and blood lead level of different age group.

\begin{tabular}{|c|l|l|}
\hline Age in years & Total No. & $\begin{array}{l}\text { Blood lead } \\
\text { Level (Mcg/dl) }\end{array}$ \\
\hline 1- 4 YEARS & 16 & $\mathbf{7 . 2 5}$ \\
\hline 5 - 8 YEARS & 24 & $\mathbf{9 . 6 4}$ \\
\hline 9 - 12 YEARS & 30 & $\mathbf{1 2 . 3 1}$ \\
\hline TOTAL & 70 & \\
\hline
\end{tabular}


Study group was divided in to 3 groups 1-4 years, 5-8 years and 9-12 years. In our study 30 out of 70 children were in 8-12 yrs age group and 24, 16 children in 5-8 yrs and 1-4 year's age group respectively. Mean blood lead level was found to be higher in 9-12 year's age group as compared to other group, where mean blood lead level was $9.64 \mathrm{mcg} / \mathrm{dl}$ in 5-8 yrs age group and 7.25 mcg/dl in 1-4 age group.

Table 2: Comparison of lead level in exposure \& non exposure group.

\begin{tabular}{|l|l|l|}
\hline Exposure to lead & Blood Lead Level & $\begin{array}{l}\text { Average IQ } \\
\text { Present 11.22 }\end{array}$ \\
\hline Present & 11.22 & 86.1 \\
\hline Absent & 9.87 & 90.83 \\
\hline
\end{tabular}

Average blood lead level in exposure group was found to be more ie. $11.22 \mathrm{mcg} / \mathrm{dl}$ as compared to non exposure group where blood lead level was found to be $9.87 \mathrm{mcg} / \mathrm{dl}$.

Table -3 Effect of nutritional status Body mass index (BMI) on blood lead level.

\begin{tabular}{|l|l|l|}
\hline BMI (Body mass index) & Blood lead level & Average IQ \\
\hline$<13$ & 10.79 & 86.3 \\
\hline $13-15$ & 11.45 & 89.69 \\
\hline$>15$ & 8.15 & 91.08 \\
\hline
\end{tabular}

To assess affect of nutritional status on blood lead level, comparison was done between blood lead level, BMI status and average IQ of the child. It was found that blood lead level was more in children with lower BMI as compared to children with normal BMI.

Table 4: Effect of blood lead level on intelligence.

\begin{tabular}{|l|l|l|}
\hline Blood lead level in mcg/dl & No of cases & Avg. IQ \\
\hline $\mathbf{0}-\mathbf{5}$ & 21 & $\mathbf{9 4 . 4}$ \\
\hline $\mathbf{5}-\mathbf{1 0}$ & 12 & $\mathbf{9 2 . 7}$ \\
\hline & & \\
\hline $10-15$ & 20 & 85 \\
\hline $\mathbf{1 5}-\mathbf{2 0}$ & 12 & $\mathbf{7 9 . 4}$ \\
\hline$<\mathbf{2 0}$ & 5 & $\mathbf{7 8 . 3}$ \\
\hline
\end{tabular}

Correlation coefficient $\mathbf{- 0 . 9 8 , ~ p ~ v a l u e ~}-\mathbf{0 . 0 0 0 0 6 4 2 8}$

This table shows the comparison of blood lead level and IQ. On studying, the relationship between blood lead level and intelligence it is very much clear that increase in blood lead level from 0 to $>20 \mathrm{mcg} / \mathrm{dl}$ was associated with decrease in average IQ from 94 to 78 point

\section{Discussion}

A large number of studies have been conducted from time to time, to assess lead status of general population including children [1, 
$2,3,4,5]$. Various studies have been also conducted to assess various factors that determine lead status of a child and impact of raised level of lead on growth and development $[1,5,6,7]$. In our study we included children of $<12 \mathrm{yrs}$ of age group attending paediatric OPD. Many studies have also been done on similar age group, one of the most important is "Project lead free" done by George foundation in seven major cities in similar age group. Prevalence was around 51\% that is comparable with our study (53\%) [1].

Lead finds its way into human body both by ingestion and inhalation, among the inhalation source, exposure to heavy traffic area has been found to be an important source of lead poisoning in most developing countries, though unleaded petrol was introduced few years back children playing near the road's pick up lead from the road side dust contaminated with automobile exhaust beside from air exposure.

In our study history of exposure to heavy traffics area was presented in 19 children with mean blood lead level high as compared to non exposure group. Most of children belong to age group of 8-12 years. The possible explanation is that they spend most of their time during play in road side areas and residence near heavy traffic area was found to be an important factor determining lead status of child. Our result were similar to study who found blood lead level to be as high $32 \mathrm{mcg} / \mathrm{dl}$ in urban city Bangalore as compared to semi urban \& rural area with average blood lead level of $25 \mathrm{mcg} / \mathrm{dl}$ and $15 \mathrm{mcg} / \mathrm{dl}$ [3].

Ingestion of lead by various sources is also important in determining the lead status of the child, as habit of Pica, hand to mouth activity is very common in children.

Take home lead exposure among children with relatives employed at a battery recycling facility was found to be an important cause of high blood lead level ina study by Puerto Rico 2011 [9].

Diet and nutritional status can be a very important factor in determining how lead toxic a child becomes. Poor nutritional state associated with multivitamins and micronutrient deficiencies besides increasing risk of absorption of lead from gastrointestinal tract makes child prone for habit of Pica, which further increases intake of lead from various sources. The deficiency of calcium, iron, and zinc enhances lead absorption. It has been recognized for many years that lead metabolism mimics calcium metabolism.

\section{Nutritional Deficiency, PICA and Lead Level}

Singhi S and co-worker (2003) in their study found that Children with low iron stores and hypozincemia are more at risk because of habit of pica [10]. Gogte et al (2000), found that habit of pica in 253 Delhi children was associated with high blood lead level of $23 \mathrm{mcg} / \mathrm{dl}$ as compared to non pica group. In our study also out of 5 children who had their blood lead level more than $20 \mathrm{mcg} / \mathrm{dl}, 3$ had habit of pica [6]. Number of children in our study was small to comment on positive association, but it is very clear that it adds to increase blood lead status of child. Many studies Glickman et al 1998, Daniel et al, Deveaux et al also found significant association between pica and elevated blood lead level [5,11,12]. As discussed earlier children with poor nutritional status and multi vitamin and micronutrient deficiency are at increased risk of lead poisoning. Hammad et al, Blake et al has also studied the effect of dietary intake of Iron, low body store of iron on G I absorption of lead. Rosen et al studied the relation of vitamin D deficiency on lead status of child $[13,14,15]$. In our study children with BMI below average was found to have blood lead level more as compared to that with normal BMI.

\section{Blood Lead level and IQ}

The critical effect of low lead exposure on cognitive and behavioural development of infants and children is a great matter of concern in modernized world.

Canfield et al 200 assessed blood lead level of 172 children at 6, 12, 18, 24, 48 and 60 months of age and applied Stanford Binet intelligence scales to assess effect of raised lead level on intelligence and concluded that there was 4.6 point dip in IQ with every $10 \mathrm{mcg} / \mathrm{dl}$ increase in lead level [16]. Approximately similar results were seen in the studies of Dietrich et.al 2003, Wasserman et.al (2003), Canfield and Henderson et.al, Lu Je et.al (2002) and Mc Michael et.al (1996), done in different age group from 1year to 12 years $[16,17,18,19]$. 
In our study with increase in blood lead level there was also associated with declining trend in intelligence, IQ at various lead level were 94.4 at $0-5 \mathrm{mcg} / \mathrm{dl}, 92.2$ at $5-10 \mathrm{mcg} / \mathrm{dl}, 85$ at $1015 \mathrm{mcg} / \mathrm{dl}, 79.4$ at $15-20 \mathrm{mcg} / \mathrm{dl}, 78.3$ at $>20 \mathrm{mcg} / \mathrm{dl}$. This decrease in intelligence with increase blood lead level was statistically significant with p value 0.0006 .

Table 5: Comparison of blood lead level and its impact on IQ

\begin{tabular}{|l|l|l|l|l|}
\hline Author & Year & Age group & $\begin{array}{l}\text { Intelligence } \\
\text { Test }\end{array}$ & Result \\
\hline Wasserman et al & 2003 & $10-12$ years & - & 4.3 full scale IQ \\
\hline Canfield et al & 2003 & 6 months- 5 years & - & 4.6 in IQ \\
\hline Wei Tsoong et al ${ }^{30}$ & 1999 & $\begin{array}{l}\text { Postnatal blood } \\
\text { sample }\end{array}$ & $\begin{array}{l}\text { Done at later } \\
\text { childhood }\end{array}$ & $\begin{array}{l}\text { At } 15 \mathrm{mcg} / \text { dl IQ } 89.36 \\
\text { At } 10.67 \text { IQ } 94.5 \%\end{array}$ \\
\hline Mc Michal et al & 1996 point \\
\hline Our Study & 2004 & $\begin{array}{l}\text { Random blood } \\
\text { sample of children } \\
1-12 \text { yrs }\end{array}$ & $\begin{array}{l}\text { Simultaneously } \\
\text { performed }\end{array}$ & $\begin{array}{l}4-5 \text { point dip in IQ with } \\
\text { every } 5 \text { mcg increase in } \\
\text { blood lead level }\end{array}$ \\
\hline
\end{tabular}

Blood Lead level and Neurobehavioral Development

Chen A et al 2007 studied the effect oflead on behaviour of child and concluded that lead independently also affect behaviour beside lowering IQ [28].

De La Burde and Choate20, 21 in their longitudinal study of 5 years on 70 preschool children with elevated level of lead, found that CNS impairment inform of fine motor function, concept formation persisted after 5 years, when assessed by variety of psychological and neurological tests. Ole Hansen et al in their study found that increase dentine lead level of more than $18.7 \mathrm{mcg} / \mathrm{dl}$ scored low on the WISC when compared to low lead children especially on verbal IQ and full scale IQ [20,21].

Study of Al Saleh et al (2001) cross sectional study on school girl of 6 to 12 years of age found that blood lead level between 9-27 $\mathrm{mcg} / \mathrm{dl}$ was associated with neuropsychological and behavioural impairment, results was similar to study of Chen A et al 2007 $[24,25]$.

Wang $\mathrm{Cl}$ et al (2002) studied impact of raised blood lead level on 32 primary school children and concluded that language ability is more affected than mathematics calculation activity [26]. Wasserman et.al (2003) in their study of 172 children from 6 months to 5 years of age found that in linear model of with each increase in $10 \mathrm{mcg} / \mathrm{dl}$ in blood lead level there was 4.6 point decrease in IQ [27].

Lisa M et al 2004 and Bellinger et al 2005 also found higher level of lead has negative impact on neurodevelopment and intelligence $[28,29]$.

Abdel Rasoul GM. et.al 201230 assessed lead level of 190 primary school children and found that blood lead level was more in urban children as compared to that of rural children and raised lead level had negative correlation with haemoglobin and IQ level. 
Table 6: Blood Lead Level and its impact on psychosocial development.

\begin{tabular}{|l|l|l|l|l|l|}
\hline Author & year & Age group & Lead level & Intelligence Test & Result \\
\hline Chen A et al & 2007 & $5-7$ years & $>10 \mathrm{mcg} / \mathrm{dl}$ & - & $\begin{array}{l}\text { Direct effect on } \\
\text { behaviour }\end{array}$ \\
\hline Lisa M. at al ${ }^{27}$ & 2004 & 7.5 years & - & - & $\begin{array}{l}\text { Neuro behavioural } \\
\text { defecit in relation to } \\
\text { intelligence, reaction } \\
\text { time }\end{array}$ \\
\hline Dietrich et al & 2003 & $6-15$ years & $\begin{array}{l}\text { Low blood } \\
\text { lead }\end{array}$ & - & $\begin{array}{l}\text { Impaired cognitive } \\
\text { development }\end{array}$ \\
\hline $\begin{array}{l}\text { Al Saleh et } \\
\mathrm{Al}^{24}\end{array}$ & 2001 & $\begin{array}{l}\text { School girls } \\
6-12 \text { years of } \\
\text { age }\end{array}$ & $9-27 \mathrm{mcg} / \mathrm{dl}$ & - & $\begin{array}{l}\text { Associated with } \\
\text { neuropsychological \& } \\
\text { behavioural impairment }\end{array}$ \\
\hline $\begin{array}{l}\text { Wang C L et } \\
\mathrm{Al}^{26}\end{array}$ & 2002 & $\begin{array}{l}32 \text { primary } \\
\text { school }\end{array}$ & $\begin{array}{l}\text { At low lead } \\
\text { level }\end{array}$ & $\begin{array}{l}\text { Academic } \\
\text { performance was } \\
\text { assessed }\end{array}$ & $\begin{array}{l}\text { Language ability is more } \\
\text { affected than } \\
\text { mathematics calculation }\end{array}$ \\
\hline $\begin{array}{l}\text { De La Burde } \\
\text { et al }{ }^{20,21}\end{array}$ & 1975 & $\begin{array}{l}\text { Follow up study } \\
\text { at 7-8 years of } \\
\text { age }\end{array}$ & $\begin{array}{l}\text { Psychological \& } \\
\text { neurological test }\end{array}$ & $\begin{array}{l}\text { Impairment of fine motor } \\
\text { function, concept } \\
\text { formation }\end{array}$ \\
\hline
\end{tabular}

\section{Conclusion}

Lead has become the most widely scattered toxic material in the world \& practically it is impossible at least in industrialized parts of the world, to find a human being who does not have some lead in his body. Progressive rise in blood lead level in a child's system can cause a child to become learning disabled.

On random sampling of children attending pediatric outpatient department, more than $50 \%$ had blood lead level above the safe level suggesting that lead is silently making way into our body and this silently entering lead is especially more dangerous for growing brain of our children as raised level of lead was significantly associated with dip in IQ status of child. However, as our sample size was small of just 70 children, to comment on lead status of generalpopulation as a whole is a difficult statement. To study the impact of lead status on intelligence of growing child there is a need to select the study group from different localities.

\section{Recommendation and limitations}

Observation of our study has clearly showed that without any apparent clinical evidence of lead toxicity, out of seventy children of study group $>50 \%$ was having lead level above safe level of $10 \mathrm{mcg} / \mathrm{dl}$. As raised level of lead and its impact on intelligence, studied in similar age group of 8-12 years was found to be statically significant. It signifies that raised level of lead is acting as slow silent poison for intelligence of our children. But as the study was done on randomly selected children from pediatric OPD, there is a need for large scale study on groups from different areas. In Developed countries screening programme for blood lead level is being done at an early age of 1-2 yrs.

Blood lead level screening of general population should also be encouraged in India, because of high prevalence of lead toxicity from various known and unknown sources.

Acknowledgement: The authors want to thank all the subjects for participation in study.

\section{References}

1. Lead poisoning prevention in India. Available online at: www.tgfworld.org/lead.htm.

2. Kalra V, Chitralekha KT, Dua T, Pandey RM, Gupta Y. Blood lead levels and risk factors for lead toxicity in children from schools and an urban slum in Delhi. J Trop Pediatr. 2003 Apr;49(2):121-3. [PubMed]

Available online at: $\underline{w w w . i j m r r . i n}$ 17 | P a g e 
3. Kumar RK, Kesaree N. Blood lead levels in urban and rural Indian children. Indian Pediatr. 1999 Mar;36(3):303-6. [PubMed]

4. Khan AH, Khan A, Ghari F, Khurshid M. Low lead level exposure and blood lead level in children: a cross sectional survey. Indian J Pediatr. 1999; 66(1): 27-35.

5. Deveaux P, Kibel MA, Dempster WS, Pocock F, Formenti $\mathrm{K}$. Blood lead level in preschool children in cape town. Sci. Total Enviro 1991; $103 \quad$ (2-3): 209-14.

6. Gogte ST, Basu N, Sinclair S, Ghai OP, Bhide NK. Blood lead levels of children with pica and surma use. Indian $\mathrm{J}$ Pediatr. 1991 Jul-Aug;58(4):513-9. [PubMed]

7. Sathaye AU, Javadekar BB. A presumptive case of lead poisoning in a brass-worker's child. J Indian Med Assoc. 2000 Aug;98(8):457-8.

[PubMed]

8. Bhatia S, Saxena SK, Khatri RL, Jain AK. Lead poisoning due to environmental pollution. Indian Pediatr. 1992 Mar;29(3):377-80.

[PubMed]

9. Singhi S, Ravishanker R, Singhi P, Nath R. Low plasma zinc and iron in pica. Indian J Pediatr. 2003 Feb;70(2):13943.

[PubMed]

10. Glickman LT, Chaudry IU, Costantino J, Clack FB, Cypess RH, Winslow L. Pica patterns, toxocariasis, and elevated blood lead in children. Am J Trop Med Hyg. 1981 Jan;30(1):77-80.

[PubMed]

11. Laraque D, McCormick M, Norman M, Taylor A, Weller SC, Karp J. Blood lead, calcium status, and behavior in preschool children. Am J Dis Child. 1990 Feb;144(2):186-9. [PubMed]

12. Am J Dis Child. 1990 Feb;144(2):186-9. Relationship between blood lead and dietary iron intake in preschool children. A cross-sectional study. Ann Epidemiol. 1996 Jan;6(1):30-3.

13. Blake K C H, Barbezat G G, Mann M. Effect of dietary constituents on G.I. absorption of pb in Man. Environ. Res. 1983; 30: 182-187.Available online at: http:/www.epa.gov/superfund/lead/ products/adultpb.pdf.
14. Rosen J F, Chesney RW, Hamstra A. Reduction of 1,25 dihydroxy vitamin-D in children with increased lead absorption. N Engl J Med. 1980 15;302(20):1128-31. [PubMed]

15. Canfield RL, Kreher DA, Cornwell C, Henderson CR Jr. Low-level lead exposure, executive functioning, and learning in early childhood. Child Neuropsychol. 2003 Mar;9(1):3553.

[PubMed]

16. Dietrich KN, Coscia JM , Ris MD, Succop PA. Cognitive Development of lead exposed from ages 6 to 15 years and application of growth curve analysis. Neuropsychol. Dev. Cogn. Sect. C Child Neuropsychol. 2003; 9(1):10-21.

17. Lü J, Zhang L, Dai Y, Liu G. [Effects of low-level lead exposure on neurobehaviour development in 1-3 year-old children and the intervention guideline]. Wei Sheng Yan Jiu. 2002 Feb;31(1):4-6. [PubMed]

18. Dhawan A, Saxena S. Effect of early exposure to lead on later childhood intellectual development. Natl Med J India. $1996 \quad$ Nov-Dec;9(6):275-6.

[PubMed]

19. de la Burdé B, Choate ML. Early asymptomatic lead exposure and development at school age. J Pediatr. 1975 Oct;87(4):638-42.

[PubMed]

20. De la Burdé B, Choate MS Jr. Does asymptomatic lead exposure in children have latent sequelae? J Pediatr. 1972 Dec;81(6):1088-91.

[PubMed]

21. Hansen ON, Trillingsgaard A, Beese I, Lyngbye T, Grandjean P. A neuropsychological study of children with elevated dentine lead level: assessment of the effect of lead in different socio-economic groups. Neurotoxicol Teratol. 1989 May-Jun;11(3):205-13.

22. Hansen O, Angen T, Besse I, Troles L, Phillippe G. learning disabilities in children : significance of low lead exposure and confounding factors. Acta Paediatr Scand. 1990; 79(3):352-60. 23. al-Saleh IA. The biochemical and clinical consequences of lead poisoning. Med Res Rev. 1994 Jul;14(4):415-86.

24. Wang CL, Chuang HY, Ho CK, Yang CY, Tsai JL, Wu TS, Wu TN. Relationship between blood lead concentrations and learning achievement among primary school children in Taiwan. Environ Res. 2002 May;89(1):12-8.

Available online at: www.ijmrr.in $\quad 18$ | P a g e 
25. Wasserman GA, Factor-Litvak P, Liu X, Todd AC, Kline JK, Slavkovich V, Popovac D, Graziano JH. The relationship between blood lead, bone lead and child intelligence. Child Neuropsychol. 2003 Mar;9(1):22-34. [PubMed].

26. Soong WT, Chao KY, Jang CS, Wang JD. Long-term effect of increased lead absorption on intelligence of children. Arch Environ Health. 1999 Jul-Aug;54(4):297-301. [PubMed]

27. Chiodo LM, Jacobson SW, Jacobson JL. Neurodevelopmental effects of postnatal lead exposure at very low levels. Neurotoxicol Teratol. 2004 MayJun;26(3):359-71.

[PubMed]
28. Chen A, Cai B, Dietrich KN, Radcliffe J, Rogan WJ. Lead exposure, IQ, and behavior in urban 5- to 7-year-olds: does lead affect behavior only by lowering IQ? Pediatrics. 2007 Mar;119(3):e650-8. [PubMed]

29. Abdel Rasoul GM, Al-Batanony MA, Mahrous OA, Abo-Salem ME, Gabr HM. Environmental lead exposure among primary school children in Shebin El-Kom District, Menoufiya Governorate, Egypt. Int J Occup Environ Med. 2012

Oct;3(4):186-94.

30. Centers for Disease Control and Prevention (CDC). Takehome lead exposure among children with relatives employed at a battery recycling facility - Puerto Rico, 2011. MMWR Morb Mortal Wkly Rep. 2012 Nov 30;61(47):967-70.

\section{How to cite this article?}

Verma J, Gaur A, Ahirwal K, Flora SJS. Study of Blood lead level and its impact on intelligence of children below 12 years of age. Int J Med Res Rev 2013;1(1):12-19. doi: 10.17511/ijmrr.2013.i01.03. 